\title{
Correlation between Corneal Endothelial Cell Characteristics and Dry Eye Disease
}

\author{
Rania Fahmy ${ }^{1,2 *}$ \\ ${ }^{1}$ Department of optometry, College of applied medical sciences, King Saud University, Saudi Arabia \\ ${ }^{2}$ Department of ophthalmology, Faculty of medicine, Cairo University, Egypt \\ *Corresponding author: Rania Fahmy, Department of ophthalmology, Faculty of medicine, Cairo University, Egypt \\ Submission: 笽October 14, 2017; Published: 㘹January 23, 2018
}

\begin{abstract}
Purpose: To correlate corneal endothelium cell density with dry eye disease compared to an age-matched control group.

Materials and Methods: In this cross-sectional study, a total of 150 eyes of 75 female students aged 19-25 years who did not have any history of eye injuries or eye disease affecting the corneal endothelium cell density, were recruited from KSU Female Campus. They were divided into groups based on their dry eye disease severity. All subjects undergone full ophthalmic examinations assessing their endothelium cell count using specular microscope and dryness level using Non-invasive Break up Time (NIBUT) using Keratograph4.
\end{abstract}

Results: The mean endothelial cell density was significantly lower in subjects with severe dryness $\left(2620.3 \pm 252.2 \mathrm{cell} / \mathrm{mm}^{2}\right)$ and moderate dryness ( $2801 \pm 221.6$ cell $/ \mathrm{mm}^{2}$ ) than normal subjects ( $3067 \pm 196.7 \mathrm{cell} / \mathrm{mm}^{2}$ ), $\mathrm{p}=.000$.In addition, the mean cell area was lower in normal subjects $\left(327.4 \pm 21.5 \mu \mathrm{m}^{2}\right)$ and increased with severity of dryness, in subjects with moderate dryness $\left(358.9 \pm 27.1 \mu \mathrm{m}^{2}\right)$ and in subjects with severe dryness $\left(384.8 \pm 33.7 \mu \mathrm{m}^{2}\right), \mathrm{p}=.000$.There was variation in the mean cell volume, in normal subjects was $(25 \pm 3.6)$ and $(27.2 \pm 4.3)$ in moderate dryness and $(25.5 \pm 3.6)$ in severe dryness, $\mathrm{p}=.009$.

Conclusion: Results succeeded to demonstrate that in moderate to severe dryness, there was a significant reduction in the corneal endothelial cell density as compared to the age- and sex-matched control group. Correlation between corneal endothelial cells Characteristics and dry eye disease Correlation between corneal endothelial cell Characteristics and dry eye disease.

Keywords: Corneal endothelium; Dryness; Specular microscope; Keratograph

\section{Introduction}

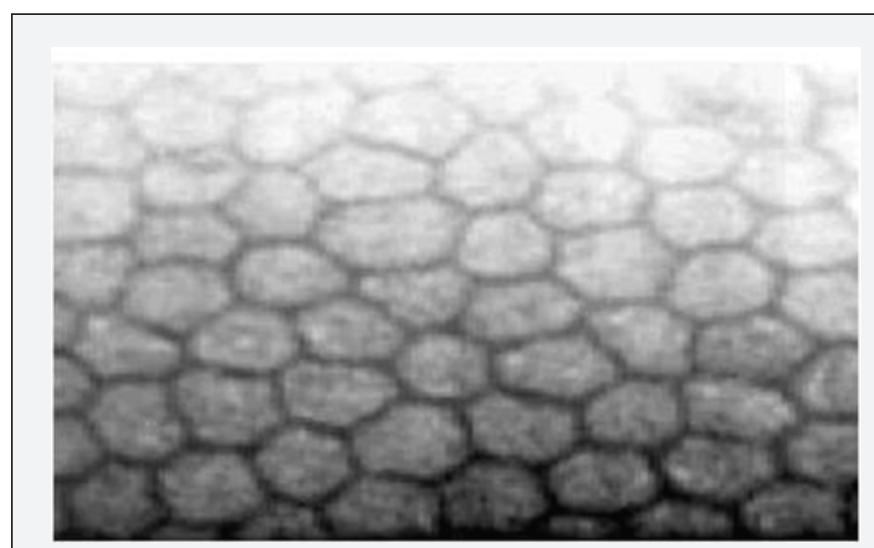

Figure 1: Specular micrograph of normal corneal endothelium cell [22].

Corneal endothelium is composed of monolayer of hexagonal cells (Figure 1), endothelium constitute the posterior corneal surface. It performs a major function in maintaining the corneal transparency, thickness and hydration [1]. The distinct arrangement of this cell layer (cell mosaic) is an eminent clinical appearance of the cornea, with images being easily captured with a specular microscope [2]. It is around $5 \mu \mathrm{m}$ thick.

The endothelium cell density reduces normally with age because of cell disintegration, ranging from 3000 to 4000 cells/ $\mathrm{mm} 2$ in children to 1000 to 2000 cells/mm2 at age of 80 years [3]. The minimum cell density must be in the range of 400 to 700 cells/ $\mathrm{mm} 2$ for prompt function of the corneal endothelium. Disruptions to the endothelial mosaic can include an increase in the variation of cell shape (pleomorphism) or size (polymegathism) and endothelial cell loss [4].

Moreover to the physiological aging process, the endothelium can be negatively influenced by disease and trauma [5]. Some diseases can harm the corneal endothelium, such as Fuchs' corneal dystrophy, leading guttae (Figure 2) and corneal edema, Additional trauma during a prolonged cataract surgery especially while extracting a hard lens nucleus [2]. This may end in endothelial cell loss. A significant change in corneal endothelial cell density was found in eyes with moderate to severe dry eye disease [6]. 


\section{Cornea Endothelium}

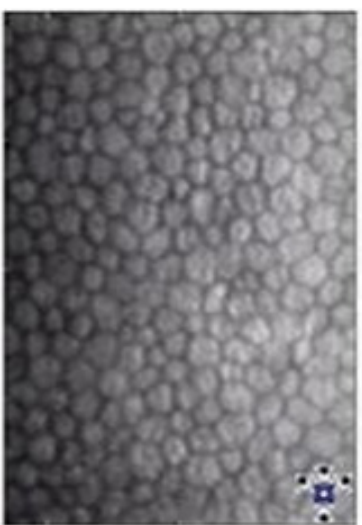

\section{Normal Endothelium High Cell Density}

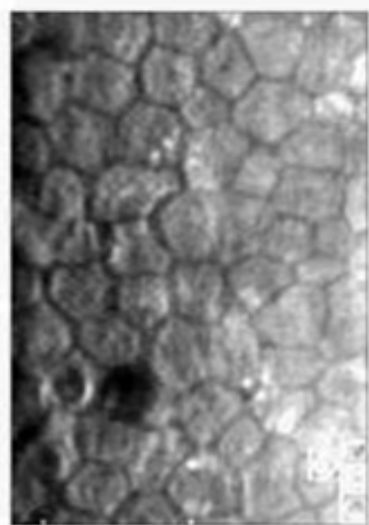

\section{Very Low Density High Surgical Risk}

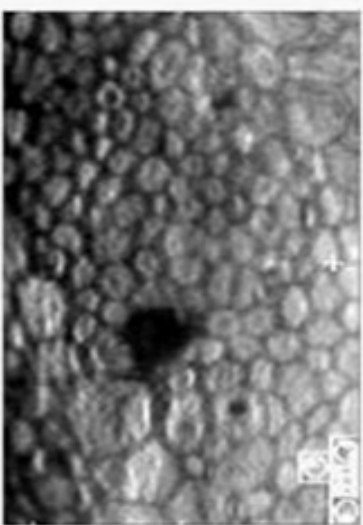

Polymegethism EW Contact Lenses

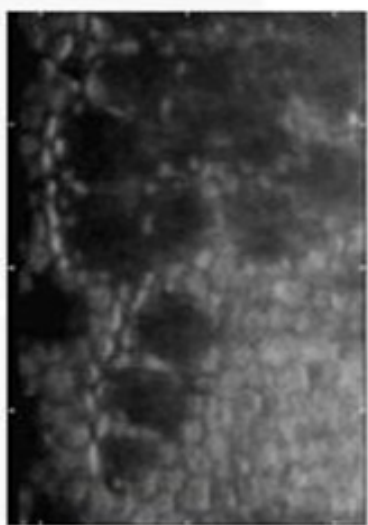

Stage 3 Guttata Normal Cell Count

Konan CellChek" Specular Microscope Imaging

Figure 2: Specular micrograph of diseased corneal endothelium.

The tear film is a pre-ocular, thin, complex and moist structure composed of four layers (lipid layer $0.1 \mu \mathrm{m}$, aqueous layer $7 \mu \mathrm{m}$, mucous layer 3-30 $\mu \mathrm{m}$ and glycocalyx $0.01-0.02 \mu \mathrm{m}$ from anterior to posterior) that covers the cornea, bulbar and palpebral conjunctiva
[7-9]. Any abnormalities to its structure will affect ocular surface and may alter corneal clarity [10]. It has optical, mechanical, nutritional, and defensive functions [11] (Figure 3).
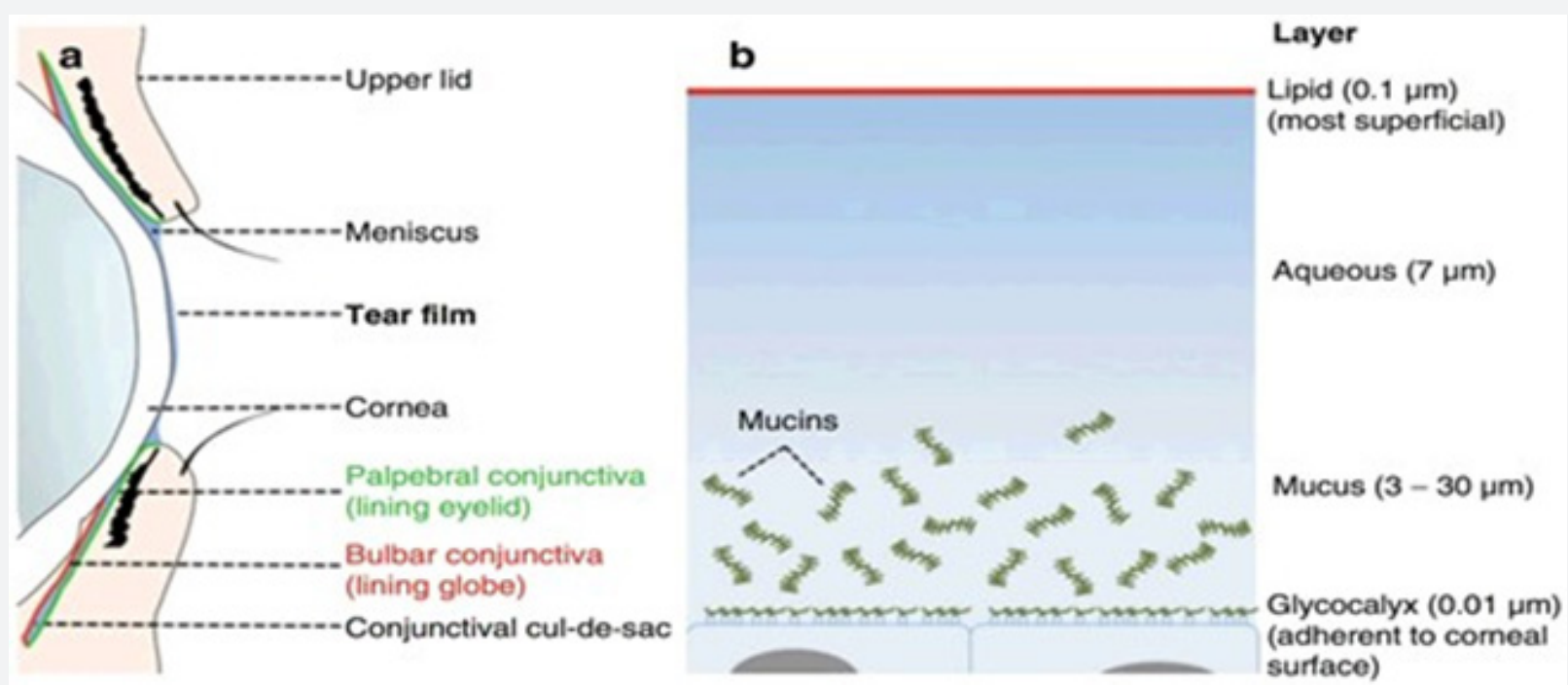

Figure 3: Theater film (a)distribution; (b) Structure [9].

Tear film total volume is $7-10 \mu$ l. Normal basal tear secretion rate is $1-2 \mu \mathrm{l} / \mathrm{min}$; on the other hand, the reflex tear rate is $>100$ $\mu \mathrm{l} / \mathrm{min}[12]$. Normal tear volume replacement occurs every $5-7 \mathrm{~min}$ [9]. Tear film thickness is around $5.35 \mu \mathrm{m}$ however the central TFT value was $5.122 \pm 0.034 \mu \mathrm{m}[13]$.

International Dry Eye Workshop's (DEWS2007) provided the following definition: "Dry eye is a multifactorial disease of the tears and ocular surface that results in symptoms of discomfort, visual disturbance, and tear film instability with potential damage to the ocular surface. It is accompanied by increased osmolality of the tear film and inflammation of the ocular surface" [14].

Any interruption to the Lacrimal Functional Unit, (a system composed of the lacrimal glands, ocular surface (cornea, conjunctiva and meibomian glands), lids, and the sensory and motor nerves that supplies them [15] can destabilize the tear film leading to hyperosmolarity and eventually to ocular surface disease. These 
two considered to be the core mechanisms of the dry eye that can initiate, intensify, and alter dry eye prosperities with time [14].

Dry eye disease is classified to two major classes' aqueous deficient dry eye and Evaporative dry eye. Both lead to tear hyperosmolarity [16]. Aqueous deficient dry eye ADDE is induced by decreased lacrimal tear production and volume leading to tear hyperosmolarity followed by inflammation $[17,18]$. It is caused by disease in the lacrimal gland (e.g. Sjögren syndrome), obstruction to lacrimal gland outflow (e.g. cicatricial pemphigoid), homeostatic disturbance induced by blockage of the afferent pathway (e.g. topical anesthesia or trigeminal nerve section), and by blockage of efferent pathway (e.g. damage to the pterygopalatine gangli on and third order neurones) [19]. It also can becaused by systemic drugs uptake [20]. ADDE is divided to Sjögren Syndrome Dry Eye (SSDE) and non-Sjögren Syndrome Dry Eye (NSSDE) [16]. Evaporative dry eye EDE is induced by increased tear evaporation rate with normal function of the lacrimal gland. It can be caused by lid related or ocular surface related diseases, also referred to as intrinsic and extrinsic EDE, respectively [16].
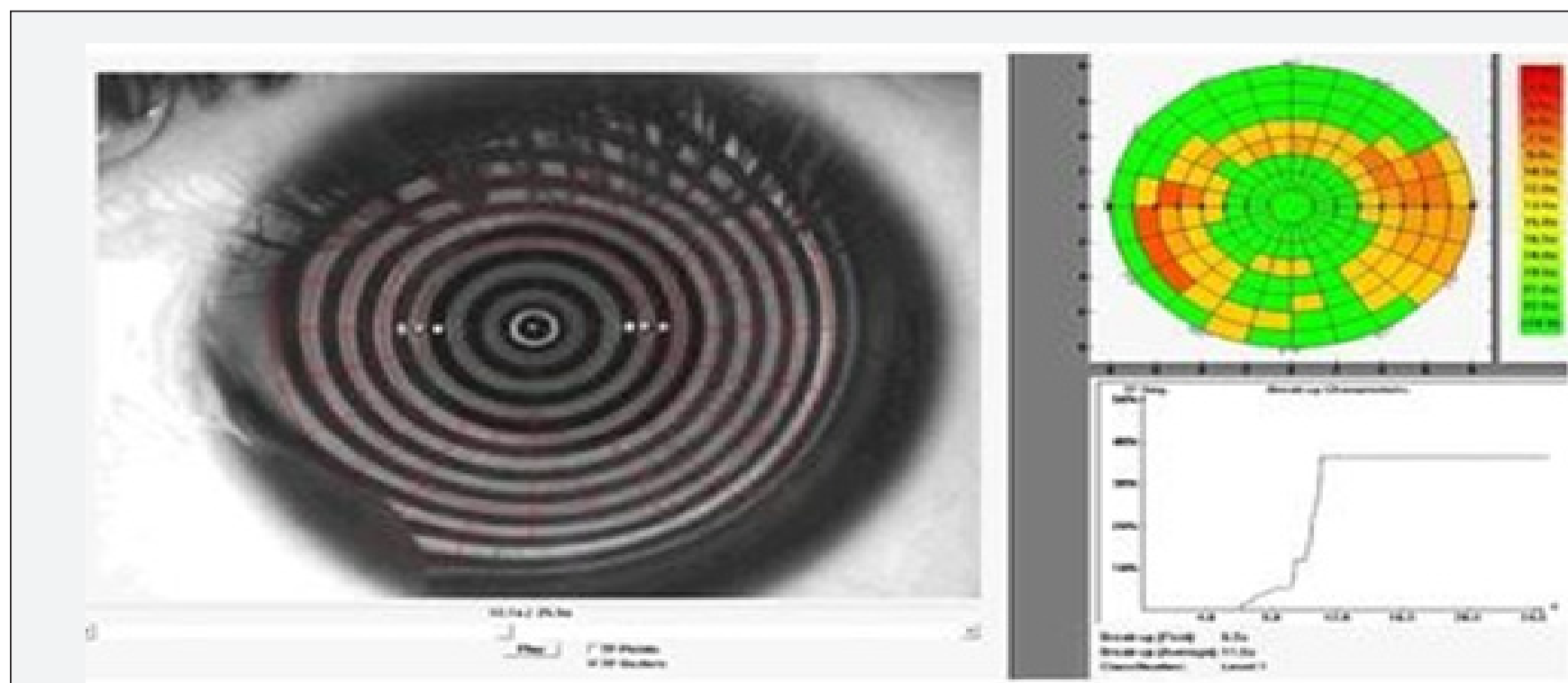

Figure 4: Non-invasive Tear Film Break Up Time (NITBUT)-Keratograph 4.

Dry eyes can be diagnosed non-invasively using Non-Invasive Tear film Breakup Time (NITBUT) and tear meniscus assessment. NITBUT is measured as the time between the last blink and the breakup of a reflected image of a target on the tear film (Figure 4). Tear meniscus assessment carries $75 \%$ to $90 \%$ of the total tear film volume. Thus, it is used to diagnose aqueous tear deficiency. Tear meniscus parameters used for tear film volume are Tear Meniscus Height TMH (the commonest) and tear meniscus radius of curvature. TMH is measured from the eye lid to the top of the meniscus, the cutoff value is $<0.1 \mathrm{~mm}$ [21] (Figure 5). Clinical examination involves the use of specular microscope and keratograph4, as non- invasive procedures, to correlate corneal endothelial cell characteristics with eye dryness.

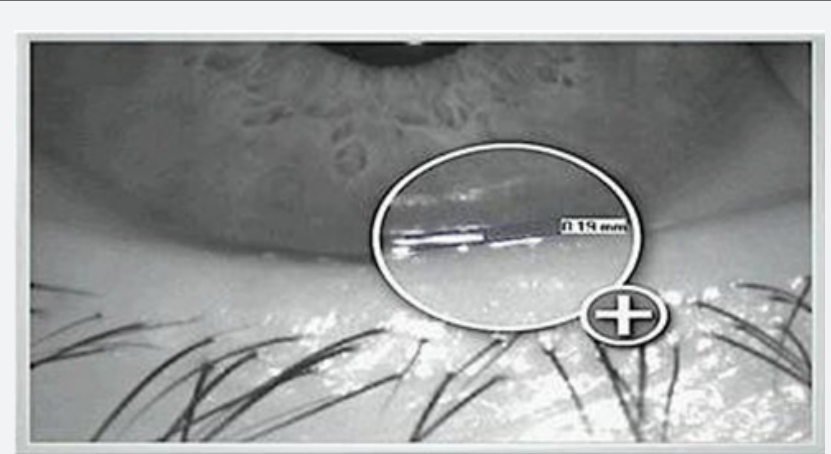

Figure 5: Tear Meniscus Height (TMH)- Keratograph 4.

\section{Methods}

Study population and Examination In this cross-sectional study, a total of 150 eyes of 75 female students aged 19-25years were recruited from King Saud University Female Campus. They were divided into groups based on their dry eye disease DED severity

a) Group 1: comprised 40 normal eyes of 20 subjects

b) Group 2: comprised 64 eyes of 32 subjects with moderate dryness

c) Group 3: comprised 46 eyes of 23 subjects with severe dryness

All subjects undergone full ophthalmic examinations including the following:

a. Measurement of refractive error using Auto Refractometer.

b. Visual acuity by Snellen chart.

c. Slitlamp examination.

d. Goldman applanation tonometry.

e. Fundoscopy.

f. Non-invasive Breakup Time (NITBUT) using Keratograph4 (to measure dryness level). 
g. Endothelium cell count using specular microscope. Subjects with break up time 10 seconds were considered to have dryness

Subjects with ocular allergic disease, keratitis, ocular surface disease, contact lens wear, glaucoma, previous ocular surgery or injury or subjects with systemic orocular treatment were excluded from this study.

\section{Statistical Analysis}

Statistical analysis was performed using SPSS version 21.0. All variables were expressed as Mean \pm Standard deviation. The normality of the data was first assessed using the Shapiro-Wilk test. Levene's test was used to determine homogeneous of the data. Owing to the normal distribution and homogeneous of the data, oneway ANOVA test was used to compare the means of endothelium cell characteristics between control group and DED groups. To assess the statistical significance of differences between means using a set of confidence intervals $95 \%$ multiple comparison post hocScheffe was used. The Pearson correlation analysis was used to estimate the correlations between the means of endothelium cell characteristics and the level of the NITBUT. The probability values of $<0.05$ were considered statically significant.

\section{Ethical consideration}

The protocol of the study was explained to each participant at the time of recruitment and informed consent was obtained according to the Declaration of Helsinki. The research was approved by the research ethical committee at College of applied medical sciences, King Saud University.

\section{Results}

The endothelial cell characteristics including Cell Density (CD), Cell Area (CA), Coefficient of Variations (CV), Hexagonality (HEX) and Center Cornea Thickness (CCT) of the three groups were studied and compared (Table 1-2).

Table 1: Endothelial cell characteristics of the study population in different NITBUT level groups (mean \pm SD).

\begin{tabular}{|c|c|c|c|c|c|c|}
\hline $\begin{array}{c}\text { NITBUT } \\
\text { level }\end{array}$ & No. of eyes & CD $\left(\mathbf{c e l l} / \mathbf{m m}^{\mathbf{2}}\right)$ & CA $\left(\boldsymbol{\mu m}^{\mathbf{2}}\right)$ & CV (\%) & HEX (\%) & CCT $\boldsymbol{\mu m})$ \\
\hline Normal & 40 & $3067 \pm 196.7$ & $327.4 \pm 21.5$ & $25 \pm 3.6$ & $68.1 \pm 3.5$ & $569.8 \pm 38.22$ \\
\hline Moderate & 64 & $2801 \pm 221.6$ & $358.9 \pm 27.1$ & $27.2 \pm 4.3$ & $66 \pm 5.2$ & $561 \pm 32.7$ \\
\hline Severe & 46 & $2620.3 \pm 252.2$ & 384.833 .7 & $25.5 \pm 3.6$ & $65.3 \pm 6.9$ & $563 \pm 23$ \\
\hline
\end{tabular}

Table 2: One way Anova.

\begin{tabular}{|c|c|c|c|c|c|c|}
\hline & & Sum of Squares & df & Mean Square & $\mathbf{F}$ & Sig. \\
\hline \multirow[t]{4}{*}{ CD } & Between Groups & 4294644.280 & 2 & 2147322.140 & 42.279 & $.000^{* *}$ \\
\hline & Within Groups & 7466006.093 & 147 & 50789.157 & & \\
\hline & Total & 11760650.373 & 149 & & & \\
\hline & Between Groups & 70407.370 & 2 & 35203.685 & 44.774 & $.000^{* *}$ \\
\hline \multirow[t]{2}{*}{ CA } & Within Groups & 115578.124 & 147 & 786.246 & & \\
\hline & Total & 185985.493 & 149 & & & \\
\hline \multirow[t]{3}{*}{ CV } & Between Groups & 149.488 & 2 & 74.744 & 4.822 & $.009^{* *}$ \\
\hline & Within Groups & 2278.672 & 147 & 15.501 & & \\
\hline & Total & 2428.160 & 149 & & & \\
\hline \multirow[t]{3}{*}{ HEX } & Between Groups & 191.462 & 2 & 95.731 & 3.177 & $.045^{*}$ \\
\hline & Within Groups & 4429.932 & 147 & 30.136 & & \\
\hline & Total & 4621.393 & 149 & & & \\
\hline \multirow[t]{3}{*}{ CCT } & Between Groups & 1803.174 & 2 & 901.587 & .896 & .411 \\
\hline & Within Groups & 146985.068 & 146 & 1006.747 & & \\
\hline & Total & 148788.242 & 148 & & & \\
\hline
\end{tabular}

\section{${ }^{*} \mathrm{P}<0.05$ significant.}

$* * \mathrm{P}<0.01$ highly significant.

The mean ECD was significantly lower in subject with severe DED $\left(2620.3 \pm 252.2 \mathrm{cell} / \mathrm{mm}^{2}\right)$ and moderate DED $(2801 \pm 221.6$ cell $/ \mathrm{mm}^{2}$ ) than normal subjects $\left(3067 \pm 196.7 \mathrm{cell} / \mathrm{mm}^{2}\right.$ ) (Figure 6), $p=.000$. In addition, the mean cell area was lower in normal subjects $\left(327.4 \pm 21.5 \mu \mathrm{m}^{2}\right)$ and increased with severity of the DED, in subjects with moderate DED $\left(358.9 \pm 27.1 \mu \mathrm{m}^{2}\right)$ and in subjects with severe DED (384.8 33.7 $\mu \mathrm{m}^{2}$ ) (Figure 7), $\mathrm{p}=.000$.
There was variation in the mean $\mathrm{CV}$, in normal subject was $(25 \pm 3.6)$ and $(27.2 \pm 4.3)$ in moderate DED and $(25.5 \pm 3.6)$ in severe DED (Figure 8), $\mathrm{p}=.009$. The mean HEX was lower in subjects with severe DED $(65.3 \pm 6.9 \%)$ and moderate DED (66 $\pm 5.2 \%)$ than normal subjects (68.1 $\pm 3.5 \%$ ) (Figure 9), $p=.045$. Mean CCT in normal subjects was $(569.8 \pm 38.22 \mu \mathrm{m})$, and $(561 \pm 32.7 \mu \mathrm{m})$, $(563 \pm 23 \mu \mathrm{m})$ in moderate and severe DED respectively (Figure 10), $\mathrm{p}=.41$. 


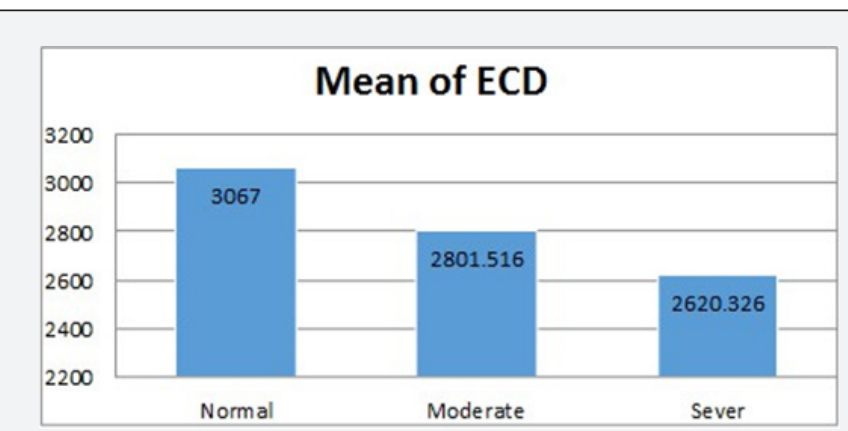

Figure 6: ECD in various groups.

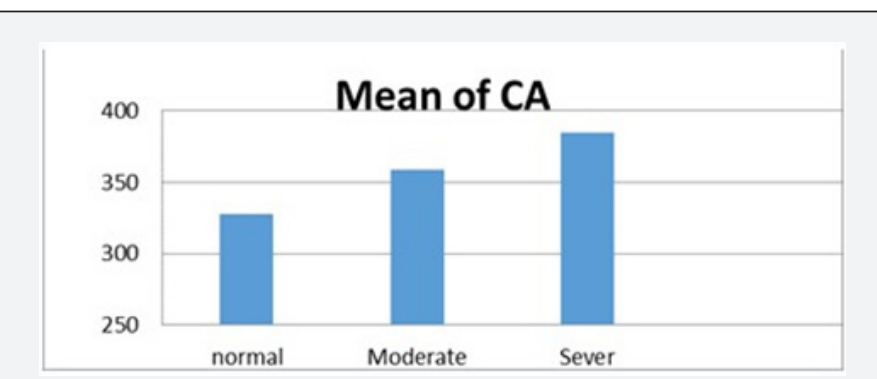

Figure 7: $\mathrm{CA}$ in various groups.

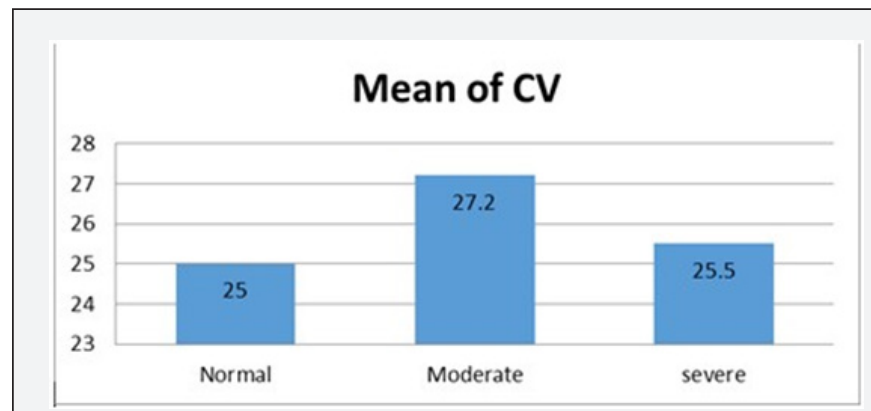

Figure 8: $\quad C V$ in various groups.

Table 3: Post hoc multiple comparisons (Scheffe).

\begin{tabular}{|c|c|c|c|c|c|c|c|}
\hline \multirow{2}{*}{$\begin{array}{l}\text { Dependent } \\
\text { Variable }\end{array}$} & \multirow{2}{*}{ (I) NIBUT level } & \multirow{2}{*}{ (J) NIBUT level } & \multirow{2}{*}{$\begin{array}{c}\text { Mean } \\
\text { Difference (I-J) }\end{array}$} & \multirow{2}{*}{ Std. Error } & \multirow{2}{*}{ Sig. } & \multicolumn{2}{|c|}{$\begin{array}{c}\text { 95\% Confidence } \\
\text { Interval }\end{array}$} \\
\hline & & & & & & $\begin{array}{l}\text { Lower } \\
\text { Bound }\end{array}$ & $\begin{array}{l}\text { Upper } \\
\text { Bound }\end{array}$ \\
\hline \multirow[t]{3}{*}{$\mathrm{CD}$} & Normal & Moderate & $265.4844^{*}$ & 45.4237 & $.000^{* *}$ & 153.156 & 377.813 \\
\hline & & Severe & $446.6739 *$ & 48.7221 & $.000^{* *}$ & 326.189 & 567.159 \\
\hline & Moderate & Severe & 181.1895* & 43.5625 & $.000^{* *}$ & 73.464 & 288.915 \\
\hline \multirow[t]{3}{*}{$\mathrm{CA}$} & Normal & Moderate & $-31.5344^{*}$ & 5.6517 & $.000^{* *}$ & -45.510 & -17.558 \\
\hline & & Severe & $-57.3543^{*}$ & 6.0620 & $.000^{* *}$ & -72.345 & -42.363 \\
\hline & Moderate & Severe & $-25.8200^{*}$ & 5.4201 & $.000^{* *}$ & -39.223 & -12.417 \\
\hline \multirow[t]{3}{*}{$\mathrm{CV}$} & Normal & Moderate & $-2.2469 *$ & .7485 & $.013^{*}$ & -4.098 & -.396 \\
\hline & & Severe & $-1.9935^{*}$ & .8028 & $.049^{*}$ & -3.979 & -.008 \\
\hline & Moderate & Severe & .2534 & .7178 & .940 & -1.522 & 2.028 \\
\hline \multirow[t]{3}{*}{ HEX } & Normal & Moderate & 2.1500 & 1.1065 & .155 & -.586 & 4.886 \\
\hline & & Severe & 2.8837 & 1.1868 & .055 & -.051 & 5.819 \\
\hline & Moderate & Severe & .7337 & 1.0611 & .788 & -1.890 & 3.358 \\
\hline
\end{tabular}

\section{Mean of HEX}

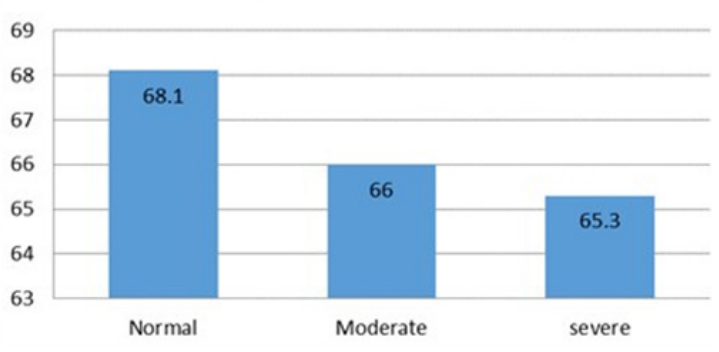

Figure 9: HEX in various groups.

CD showed higher statistically significant difference between normal to severe DED with mean difference $\left(446.67 \mathrm{cell} / \mathrm{mm}^{2}\right.$ ) $(\mathrm{P}=.000)$ than between normal to moderate $\mathrm{DED}$ with mean difference $\left(265.48\right.$ cell $\left./ \mathrm{mm}^{2}\right)(P=.000)$ and between moderate to severe DED with mean difference $\left(181.18\right.$ cell $\left./ \mathrm{mm}^{2}\right)(\mathrm{P}=.000)$.

CA showed higher statistically significant difference between normal to severe DED with mean difference $\left(-57.35 \mu \mathrm{m}^{2}\right)(\mathrm{P}=.000)$ than between normal to moderate DED with mean difference $\left(-31.53 \mu \mathrm{m}^{2}\right)(\mathrm{P}=.000)$ and between moderate to severe DED with mean difference $(-25.82 \mu \mathrm{m})(\mathrm{P}=.000)$.

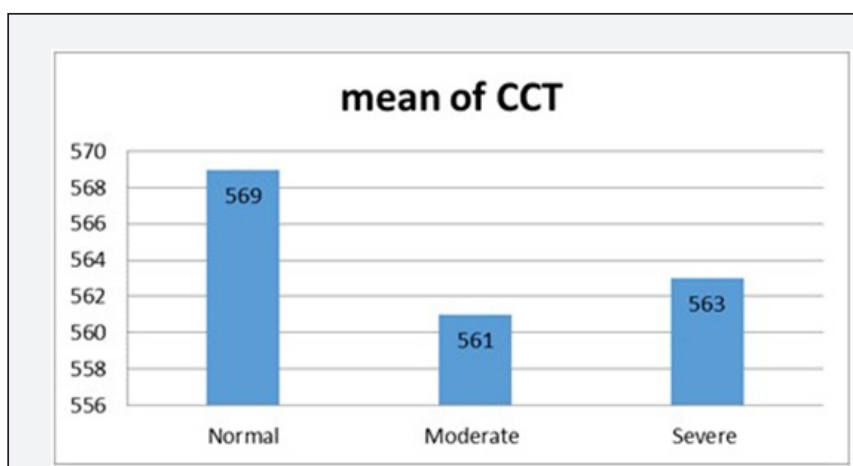

Figure 10: $\mathrm{CCT}$ in various groups. 


\begin{tabular}{|c|c|c|c|c|c|c|c|}
\hline CCT & Normal & Moderate & 8.3512 & 6.4147 & .431 & -7.513 & 24.215 \\
\hline & & Severe & 6.8533 & 6.8596 & .608 & -10.111 & 23.818 \\
\hline & Moderate & Severe & -1.4979 & 6.1535 & .971 & -16.716 & 13.720 \\
\hline
\end{tabular}

CV showed higher statistically significant difference between normal to moderate DED with mean difference $(-2.24 \%)(\mathrm{P}=.013)$ than between normal to severe DED with mean difference $(-1.99 \%)$ $(\mathrm{P}=.049)$ with no statistically significant between moderate to severe DED with mean difference (0.25\%) (P=.94).

HEX showed no statistically significant difference between normal to moderate DED with mean difference $(2.15 \%) \quad(P=.15)$ and between normal to severe DED with mean difference $(2.88 \%)$ $(\mathrm{P}=.05)$ and between moderate to severe DED with mean difference (0.73\%) (P=.78).

normal to moderate DED with mean difference $(8.35 \mu \mathrm{m})(\mathrm{P}=.43)$ and between normal to severe DED with mean difference $(6.85 \mu \mathrm{m})$ $(\mathrm{P}=.60)$ and between moderate to severe DED with mean difference $(-1.49 \mu \mathrm{m})(\mathrm{P}=.97)$ (Table 3).

The ECD showed statistically significant negative correlation with the NITBUT level ( $\mathrm{rs}=-.6, \mathrm{P}=0.000$ ), CA showed statistically significant positive correlation with the NITBUT level ( $\mathrm{rs}=.61$, $\mathrm{P}=0.000)$, CV showed weak positive correlation with the NITBUT level (rs=.191 P=0.19), HEX showed weak negative correlations with the NITBUT level ( $\mathrm{rs}=-.194 \mathrm{P}=0.18$ ), and CCT showed irrelevant (very weak) negative correlations with the NITBUT level (Table 4).

CCT showed no statistically significant difference between

Table 4: Comparison between NITBUT and Endothelial cell characteristics.

\begin{tabular}{|c|c|c|}
\hline Parameter (mean) & $\mathbf{r}$ (personcorrelation) & p-value \\
\hline $\mathrm{CD}\left(\mathrm{cell} / \mathrm{mm}^{2}\right)$ & $-.600^{*}$ & $0.000^{* *}$ \\
\hline $\mathrm{CA}\left(\mu \mathrm{m}^{2}\right)$ & $.614^{*}$ & $0.000^{* *}$ \\
\hline $\mathrm{CV}(\%)$ & $.191^{*}$ & $.019^{*}$ \\
\hline $\operatorname{HEX}(\%)$ & -.194 & .018 \\
\hline $\mathrm{CCT}(\mu \mathrm{m})$ & -.079 & .340 \\
\hline
\end{tabular}

Discussion

\begin{tabular}{|c|c|c|c|}
\hline Author & No. of subjects & Instrument used & Result \\
\hline $\begin{array}{l}\text { Current } \\
\text { Study } \\
2017\end{array}$ & $\begin{array}{c}\text { Group1:40 normal eyes of } 20 \\
\text { subjects } \\
\text { Group2:64eyes of } 32 \text { subjects } \\
\text { with moderate } \\
\text { dryness } \\
\text { Group3:44 eyes of } 22 \text { subjects } \\
\text { with severe } \\
\text { dryness }\end{array}$ & $\begin{array}{l}\text { Specular microscopy } \\
\qquad \text { CEM-530 } \\
\text { NITBUT Keratograph4 }\end{array}$ & $\begin{array}{l}\text { This cross-sectional study showed } \\
\text { That in moderate to severe DED, there was a significant } \\
\text { reduction in the corneal endothelial cell density (ECD) } \\
\text { as compared to the age-and sex-matched control group. } \\
\text { ECD showed significant correlation with clinical severity } \\
\text { of the disease, as judged by the level of non-invasive } \\
\text { tear breakup time test. In addition, in DED there is a } \\
\text { significant reduction in percentage of hexagonal cells } \\
\text { (Polymegathism) and an increase in endothelial cell area } \\
\text { and coefficient of variation (pleomorphism) that correlates } \\
\text { With clinical severity of the disease. }\end{array}$ \\
\hline $\begin{array}{l}\text { Kheirkh } \\
\text { et al. } 2015\end{array}$ & $\begin{array}{l}15 \text { normal subjects } \\
45 \text { patientswith } \\
\text { DED. }\end{array}$ & $\begin{array}{l}\text { IVCM using a } \\
\text { Heidelberg Retina Tomography3 } \\
\text { With the Rostock Cornea } \\
\text { Module. }\end{array}$ & $\begin{array}{l}\text { Eyes with DED displayed a } \\
\text { Significant reduction in corneal ECD indeed that correlates } \\
\text { with clinical severity of the disease and Significant lower } \\
\text { sub basal nerve density than did those in the control group. }\end{array}$ \\
\hline $\begin{array}{l}\text { RohitShettyetal. } \\
2015\end{array}$ & $\begin{array}{l}43 \text { healthy control } \\
\text { 52DEDpatients }\end{array}$ & $\begin{array}{l}\text { IVCM imaging using Rostock } \\
\text { Corneal Module/Heidelberg } \\
\text { Retina Tomograph ll }\end{array}$ & $\begin{array}{c}\text { A significant decrease in SBNP } \\
\text { features (corneal nerve fiber length, fiber density, fiber } \\
\text { width, total branch density, nerve branch density, and fiber } \\
\text { area) was observed in DED patients with }\end{array}$ \\
\hline $\begin{array}{l}\text { Ceyhun } \\
\text { Arıcı, et } \\
\text { al. } 2014\end{array}$ & $\begin{array}{c}252 \text { eyes of } 126 \text { healthy } \\
\text { volunteers }\end{array}$ & Specular microscopy & $\begin{array}{l}\text { It has been reported that there is a } \\
\text { negative correlation between CA and CD. }\end{array}$ \\
\hline $\begin{array}{l}\text { Bernardo } \\
\text { Bercht, et al.,2014 }\end{array}$ & $\begin{array}{l}\text { Group } 1 \text { (2-4- month-old) } \\
\text { Group } 2 \text { (48- month-old) } \\
\text { Group } 3 \text { (10years of age). }\end{array}$ & Specular microscopy & $\begin{array}{l}\text { It has been reported that there is a } \\
\text { negative correlation between endothelial cell density and } \\
\text { an endothelial cell area and pleomorphism. Pleomorphism. }\end{array}$ \\
\hline
\end{tabular}




\section{Conclusion}

In conclusion, results succeeded to demonstrate that in moderate to severe DED, there was a significant reduction in the corneal Endothelial Cell Density (ECD) as compared to the age- and sex-matched control group. ECD showed significant correlation with clinical severity of the disease, as judged by the level of non-invasive tear breakup time test. In addition, in DED there is a significant reduction in percentage of hexagonal cells (Polymegethism) (-ve) and an increase in endothelial cell area and coefficient of variation (pleomorphism) (+ve) that correlates with clinical everity of the disease.

\section{Acknowledgement}

This research project was supported by a grant from the "Research Center of the Female Scientific and Medical Colleges", Deanship of Scientific Research, King Saud University.

\section{Declaration of Interest}

The author declares no potential conflicts of interest with respect to the authorship, and/or publication of this article.

\section{References}

1. Peh GS, Beuerman RW, Colman A, Tan DT, Mehta JS (2011) Human Corneal Endothelial Cell Expansion for Corneal Endothelium Transplantation: an Overview. Transplantation 91(8): 811-819.

2. Herranz RM, Herran RC (2012) Occular Surface. Section I: Anatomy and Physiology of the Ocular Surface.

3. Remington LA, Remington LA (2012) Clinical anatomy and physiology of the visual system. St. Louis, MO: Elsevier/Butterworth Heinemann.

4. McCarey BE, Edelhauser HF, Lynn MJ (2008) Review of Corneal Endothelial Specular Microscopy for FDA Clinical Trials of Refractive Procedures, Surgical Devices, and New Intraocular Drugs and Solutions. Cornea 27(1): 1-16.

5. Rozhko A, Rodzina E, Savasteeva I, Maria R (2013) Endothelial dysfunction in diabetes mellitus. Endocrine Abstracts EJEA.

6. Kheirkhah A, Saboo US, Abud TB, Dohlman TH, Arnoldner MA, et al. (2015) Reduced Corneal Endothelial Cell Density in Patients with Dry Eye Disease. Am J Ophthalmol 159(6): 1022-1026.

7. Forrester JV, Dick AD, Mc Menamin PG, Roberts F, Pearlman E (2015) The Eye: Basic Sciences in practice: Elsevier Health Sciences UK pp. 568.
8. Johnson ME, Murphy PJ (2004) Changes in the tear film and ocular surface from dry eye syndrome. Prog Retin Eye Res 23(4): 449-474.

9. Skalicky SE (2015) Ocular and Visual Physiology: Clinical Application. Springer Singapore pp. 366.

10. Tiffany JM (2008) The normal tear film. Dev Ophthalmol 41: 1-20.

11. Gipson IK (2007) The Ocular Surface: The Challenge to enable and protect vision the Friedenwald Lecture. Invest Ophthalmol Vis Sci 48(10): 4391-4398.

12. Murube J (2009) Basal reflex, and psycho-emotional tears. Ocul Surf $7(2): 60-66$.

13. Aranhados Santos V, Schmetterer L, Gröschl M, Garhofer G, Schmidl D, et al. (2015) In vivo tear film thickness measurement and tear film dynamics visualization using spectral domain optical coherence tomography. Opt Express 23(16): 21043-21063.

14. Dews (2007) The definition and classification of dry eye disease: report of the Definition and Classification Subcommittee of the International Dry Eye Workshop. Ocul Surf 5(2): 75-92.

15. Stern ME, Beuerman RW, Fox RI, Gao J, Mircheff AK, et al. (1998) The pathology of dry eye: the interaction between the ocular surface and lacrimal glands. Cornea 17(6): 584-589.

16. Chan C (2015) Dry Eye: A Practical Approach: Springer Berlin Heidelberg.

17. Li DQ Chen Z, Song XJ, Luo L, Pflugfelder SC (2004) Stimulation of matrix metalloproteinases by hyperosmolarity via a JNK pathway in human corneal epithelial cells. Invest Ophthalmol Visual Sci 45(12): 4302-4311.

18. Luo L, Li DQ Corrales RM, Pflugfelder SC (2005) Hyperosmolar saline is a proinflammatory stress on the mouse ocular surface. Eye Contact Lens. 31(5): 186-193.

19. Vitale S, Goodman LA, Reed GF, Smith JA (2004) Comparison of the NEI-VFQ and OSDI questionnaires in patients with Sjögren's syndromerelated dry eye. Health Qual Life Outcomes 2: 44.

20. Fraunfelder FT, Sciubba JJ, Mathers WD (2012) The role of medications in causing dry eye. Journal of ophthalmology p. 8.

21. Dews (2007) Methodologies to diagnose and monitor dry eye disease: Report of the Diagnostic Methodology Subcommittee of the International Dry Eye Work Shop. Ocul Surf 5(2): 108-152.

22. João AT PigattoI, Cristine CervaI, Cesar D FreireI, Fernando C AbibII, Luciano P Bellini (2008) Morphological analysis of the corneal endothelium in eyes of dogs using specular microscopy. Rio de Janeiro 28(9). 